\title{
Vaginal foreign body: Successful management with vaginoscopy
}

\author{
Vajende yabancı cisim: Vajinoskopi ile başarıla yönetimi
}

\author{
Şükrü Yıldız, Murat Ekin, Hüseyin Cengiz, Hediye Dağdeviren, Cihan Kaya \\ Department of Obstetrics and Gynecology, Bakirköy Dr. Sadi Konuk Education and Research Hospital, istanbul Turkey
}

\section{Abstract}

The etiology of chronic vaginal discharge in children varies and can be seen as infection, sexual abuse, congenital malformations, vulvar skin disease, vaginal neoplasms and a foreign body. A vaginal foreign body is not a common problem in childhood but it should always be considered when a little girl consults a physician with a chronic vaginal discharge problem. We present the diagnosis and treatment management via vaginoscopy applied to a 6 year old girl who complained of a foul smelling vaginal discharge that had been resistant to medical treatment for the last two years. (J Turkish-German Gynecol Assoc 2013; 14: 46-7)

Key words: Chronic vaginal discharge, foreign bodies, vaginoscopy, diagnosis, treatment

Received: 02 February, 2013

Accepted: 08 February, 2013
Özet

Çocuklarda kronik vajinal akıntı nedenleri arasında enfeksiyon, cinsel istismar, konjenital malformasyonlar, vulvar deri hastalıkları, vajinal neoplazmlar ve yabancı cisim yer alır. Vajinal yabancı cisim çocukluk çağında yaygın bir neden değildir ancak kronik vajinal akıntı ile başvuran bir kız çocuğunda her zaman akılda tutulmalıdır. Bu yazıda, son 2 yıldır medikal tedaviye dirençli kötü kokulu vajinal akıntısı olan 6 yaşındaki bir kız çocuğunun vajinoskopi ile tanı ve tedavi yönetimini sunduk. (J Turkish-German Gynecol Assoc 2013; 14: 46-7)

Anahtar kelimeler: Kronik vajinal akıntı, yabancı cisim, vajinoskopi, tanı, tedavi

Geliş Tarihi: 02 Şubat 2013

Kabul Tarihi: 08 Şubat 2013

\section{Introduction}

The etiologies of chronic vaginal discharge in children are various such as infection, sexual abuse, congenital malformations, vulvar skin disease, vaginal neoplasms and a foreign body (1). A vaginal foreign body is not a common problem in childhood, but it should always be considered when a little girl consults a physician with the chronic vaginal discharge problem. We present the diagnosis and treatment management via vaginoscopy applied in a 6 year old girl who complained of a foul smelling vaginal discharge that had been resistant to medical treatment for the last two years.

\section{Case Report}

A 6 year old girl was referred to our clinic with persistant vaginal discharge. She had been treated several times with antibiotics by gynecologists. The girl and her mother denied foreign body insertion or sexual abuse. The discharge was intermittently purulent and smelly. Physical examination revealed normal external genitalia. A mild amount of discharge and erythema of vulva was seen (Figure 1). Without any scars or rupture, the hymen was not disturbed. A vaginal swab was sent for microbial culture, which revealed Escherichia coli. Urine analysis revealed leukocyturia. Pelvic ultrasound showed normal findings. In addition, the urine culture result was not significant. It was decided that the patient should be admitted to the gynecological department for examination under general anesthesia. A hysteroscope was inserted into the vagina without disrupting the hymen. Vaginoscopy with 'no-touch technique' was performed with a $5 \mathrm{~mm}$ operative office hysteroscope (Karl-Storz, Tutlingen, Germany) and the foreign bodies were revealed. The foreign bodies were removed by forceps with gentle traction. There were two parts of a pencil and a hairgrip (Figure 2). She was discharged on the first postoperative day. In subsequent visits, the girl and her mother reported the cessation of discharge and physical examinations revealed normal findings.

\section{Discussion}

The prevalence of vaginal foreign bodies in girls under 13 years of age with gynecological disorders was found to be $4.0 \%$ (2). Foreign body insertion into the vagina in childhood is uncommon but it is very interesting. Such foreign bodies are introduced into the vagina either due to the curiosity of the child or for sexual satisfaction. Small pieces of toilet paper that are found in the vagina are the most common (3). An interesting variety of foreign bodies, such as safety pins, pencils, toys, sweets, seeds, fruits were found in the vagina. 


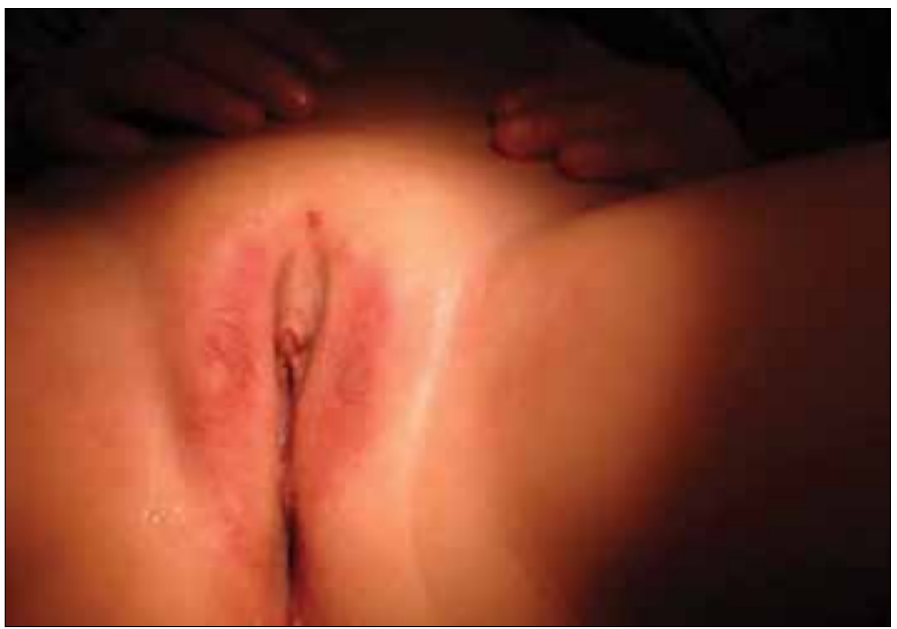

Figure 1. Erythema of vulva

Written informed consent was obtained from the parent of the patient for publication of this case report and any accompanying images

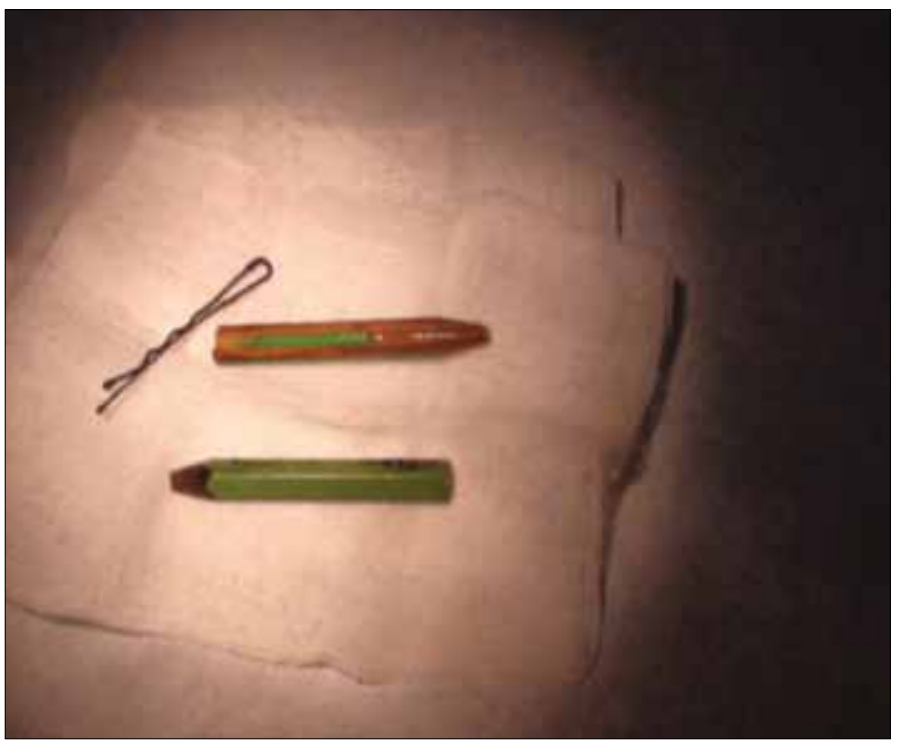

Figure 2. Vaginal foreign bodies

When a child presents with persistent or relapsing foul smelling vaginal discharge, one should always look for a foreign body in the vagina (4). Stricker et al. (5) reported that $49 \%$ of girls with a vaginal foreign body had presented with vaginal discharge. Also, a study review performed by Striegel et al. (6) reported that the etiology of vaginal discharge in girls younger than 6 years who underwent examination under general anesthesia in $45 \%$ of the cases was foreign bodies in the vagina.
Diagnosis of foreign bodies in the vagina includes careful history taking, genital examination, pelvic ultrasound, pelvic radiography and Magnetic Resonance Imaging (MRI). MRI is regarded as the best technique for evaluating vaginal foreign bodies in young children (7). However, it is not always available or necessarily conclusive. Vaginoscopy with $4 \mathrm{~mm}$ hysteroscope under general anesthesia is very useful for detection and treatment of vaginal foreign bodies (8).

In our case, we managed the patient with vaginoscopy without disrupting the hymen. We believe that examination under anesthesia should be the first line of investigation in cases of resistant chronic vaginal discharge because pelvic ultrasound, plain radiography and MRI are not always helpful in detecting foreign bodies in the vagina.

In conlusion, if a child presents with chronic vaginal discharge, the possibility of a vaginal foreign body should be considered. Diagnostic procedures may be more available and helpful, but vaginoscopy is a very important means of diagnosis and treatment of vaginal foreign bodies in childhood.

\section{Conflict of interest}

No conflict of interest was declared by the authors.

\section{References}

1. Jaquiery A, Stylianopoulos A, Hogg G, Grover S. Vulvovaginitis: clinical features, aetiology, and microbiology of the genital tract. Arch Dis Child 1999; 81: 64-7. [CrossRef]

2. Paradise JE, Willis ED. Probability of vaginal foreign body in girls with genital complaints. Amer J Dis Child 1985; 139: 472-6.

3. Pokorny SF. Long term intra-vaginal presence of foreign body in children. A preliminary study. J Reproductive Med 1994; 39: 931-5.

4. Smith UR, Berman DR, Quint EH. Premenarchal vaginal discharge, findings of procedures to rule out foreign bodies. J Pediatr Adolesc Gynecol 2002; 15: 227-30. [CrossRef]

5. Stricker T, Narratil F, Sennhauser FH. Vaginal foreign bodies. J Pediatr Child Health. 2004; 40: 205-7. [CrossRef]

6. Striegel AM, Myers JB, Sorensen MD, Furness PD, Koyle MA. Vaginal discharge and bleeding in girls younger than 6 years. J Urol 2006; 176: 2632-5. [CrossRef]

7. Kihara M, Sato N, Kimura H, Kamiyama M, Sekiya S, Takano H. Magnetic resonance imaging in the evaluation of vaginal foreign bodies in a young girl. Arch Gynecol Obstet 2001; 265: 221-2. [CrossRef]

8. Golan A, Lurie S, Savig R, Glezerman M. Continuous-flow vaginoscopy in children and adolescents. J Am Assoc Gynecol Laparasc 2000; 7: 526-8. [CrossRef] 